Jurnal Teknik Komputer AMIK BSI

Volume 7, No.2, Juli 2021

P-ISSN 2442-2436, E-ISSN: 2550-0120

Akreditasi Ristekdikti, No: 36/E/KPT/2019 (Sinta 4)

DOI: $10.31294 /$ jtk.v4i2

\title{
Aplikasi Monitoring Kehadiran Siswa Berbasis Web Untuk Mendukung Pembelajaran Jarak Jauh
}

\author{
Mia Rosmiati \\ Program Studi Sistem Informasi Fakultas Teknik dan Informatika \\ Universitas Bina Sarana Informatika \\ e-mail: mia.mrm@bsi.ac.id

$\begin{array}{ccc}\text { Diterima } & \text { Direvisi } & \text { Disetujui } \\ 24-03-2021 & 21-06-2021 & 28-06-2021\end{array}$

\begin{abstract}
Abstrak - Di masa Pandemi Covid-19 yang tengah dihadapi di Indonesia, Pembelajaran Jarak Jauh bagi seluruh siswa/siswi merupakan salah satu jalan yang ditempuh untuk mengurangi penyebaran virus corona. Penerapan kegiatan pembelajaran jarak jauh di Indonesia mengalami banyak kendala karena baik guru, siswa/siswi terbiasa melakukan kegiatan belajar mengajar dengan bertatap muka secara langsung. Permasalahan yan terjadi adalah banyak siswa yang tidak mengikuti kegiatan belajar, tidak mengerjakan tugas sehingga mengakibatkan siswa tersebut dianggap tidak hadir. Sulitnya guru melakukan monitoring terhadap siswa merupakan alasan dikembangkannya aplikasi monitoring kehadiran siswa berbasis web yang dibahas dalam penelitian ini. Sistem yang dikembangkan menggunakan Model SCRUM yang terdiri dari Requierement Gathering, Product Backlog, Sprint Backlog, Sprint, dan Information System Develpoment. Dengan dikembangkannya aplikasi monitoring kehadiran siswa dapat membantu guru maupun wali kelas dalam melakukan pengolahan data kehadiran siswa secara cepat, tepat dan akurat. Menghasilkan laporan kehadiran siswa yang akurat dapat membantu pihak sekolah yang terkait dalam proses evaluasi sistem Pembelajaran Jarak Jauh dan juga sebagai bahan pertimpabngan kepala sekolah dalam pengambilan keputusan.
\end{abstract}

Kata Kunci: kehadiran, monitoring, scrum

\begin{abstract}
During the Covid-19 Pandemic that is currently being faced in Indonesia, Distance Learning for all students is one of the ways taken to reduce the spread of the corona virus. The application of distance learning activities in Indonesia experiences many obstacles because both teachers and students are accustomed to faceto-face teaching and learning activities. The problem that occurs is that many students do not participate in learning activities, do not do assignments, resulting in these students being considered absent. The difficulty of teachers in monitoring students is the reason for the development of the web-based student attendance monitoring application discussed in this study. The system developed uses the SCRUM Model which consists of Requierement Gathering, Product Backlog, Sprint Backlog, Sprint, and Information System Development. With the development of a student attendance monitoring application, it can help teachers and homeroom teachers in processing student attendance data quickly, precisely and accurately. Producing accurate student attendance reports can help schools involved in the process of evaluating the Distance Learning system and also as material for the principal's involvement in decision making.
\end{abstract}

Keywords: attendance, monitoring, scrum

\section{PENDAHULUAN}

Indonesia tengah mengalami Pandemi Global Covid19 selama kurang lebih satu tahun. Sejak bulan Maret 2020 pemerintah sudah memberlakukan Pembatasan Sosial Berskala Besar (PSBB) untuk mencegah penularan Covid-19. Dengan diberlakukannya PSBB pemerintah melakukan pembatasan kegiatan di berbagai sektor yang ada di Indonesia, salah satunya adalah di bidang pendidikan. Sampai saat ini sebagaian besar sekolahsekolah maupun perguruan tinggi yang ada di
Indonesia masih melakukan Pembelajaran Jarak Jauh (PJJ).

Pemberlakuan penutupan sekolah yang dimulai tanggal 16 Maret 2020 mengharuskan semua sekolah terutama yang ada di Jakarta melaksanakan kegiatan belajar mengajar yang dilakukan di rumah masing-masing. Guru dan murid tidak diperbolehkan datang ke sekolah dan proses belajar mengajar dilakukan dengan jarak jauh (Rosmiati, 2020). 
Menurut (Riyandi et al., 2020), Sistem pembelajaran jarak jauh ini merupakan salah satu solusi yang tepat untuk diterapkan di masa pandemi saat ini agar kegiatan belajar mengajar tetap dapat terlaksana dengan baik dan menyelamatkan para peserta didik agar selalu di rumah dan meminimalisir terjadinya penularan virus corona.

Namun, banyak sekali kendala yang dihadapi dalam pelaksanaan PJJ ini. Baik dari sisi guru, siswa, dosen, ataupun mahasiswanya. Salah satu permasalahan yang terjadi berkaitan dengan kehadiran siswa dalam mengikuti kegiatan PJJ. Di Indonesia pendidikan di sekolah terbiasa dengan kegiatan tatap muka. Oleh karena itu dibutuhkan kesadaran yang cukup tinggi untuk para siswa mengikuti kegiatan pembelajaran secara online. Di mana siswa harus tetap mengikuti pelajaran menggunakan aplikasi online dari rumahnya masingmasing. Ditingkat menengah banyak siswa yang tidak mengikuti kegiatan PJJ sehingga guru-guru harus melakukan pengawasan yang ketat terhadap siswa yang ada di sekolah menengah. Salah satu cara yang dilakukan oleh guru adalah melakukan komunikasi secara intens melalui media sosial kepada siswanya untuk selalu mengikuti kegiatan PJJ, bahkan guru juga melakukan kunjungan ke rumah untuk siswa yang tidak aktif dalam mengikuti kegiatan PJJ. Guru juga diwajibkan untuk selalu melaporkan kepada kepala sekolah mengenai kondisi siswanya.

Untuk memudahkan guru dalam melakukan monitoring dan pelaporan kondisi siswanya kepada kepala sekolah dibutuhkan suatu sistem yang dapat memudahkan proses pelaporan kondisi siswa tersebut. Salah satu solusi yang dapat diberikan yaitu membangun sebuah aplikasi monitoring kehadiran siswa yang dilakukan oleh guru sehingga nantinya dapat langsung dilaporkan kepada kepala sekolah ataupun orang tua siswa secara cepat, tepat dan akurat.

Banyak orang tua siswa yang tidak mengetahui bagaimana perkembangan anaknya dalam mengikuti kegiatan pembelajarn jarak jauh dikarenakan kesibukan orang tua dan juga posisi mereka yang kemungkinan berada di luar kota untuk bekerja. Bahkan karena anak kurang terbuka dengan masalah nilai yang diperoleh di sekolah (Putri et al., 2016).

Menurut (Kurniawan \& Akbar, 2020), belum adanya aplikasi yang dapat digunakan untuk monitoring absensi per mata pelajaran dan monitoring materi pelajaran yang diberikan guru berdasarkan kompetensi dasar pembelajaran. Dan juga belum adanya sistem monitoring yang dapat memudahkan kepala sekolah dalam melakukan pengawasan terhadap guru-guru, menyebabkan bertumpuknya dokumen-dokumen adminitrasi akademik sehingga membutuhkan waktu yang relatif lama dalam proses pencarian data dan pengelolaan lainnya, terlebih seluruh dokumen dalam bentuk kertas, salah satunya adalah jurnal kelas.

Proses Monitoring dilakukan untuk mengetahui kesesuaian antara rencana pembelajaran yang telah disusun dengan penerapan yang dilakukan oleh para guru. Proses ini juga dapat digunakan untuk bahan evaluasi dalam memperbaiki kegiatan yang kurang sesuai dari rencana dan mengoreksi penyalahgunaan aturan agar mencapai tujuan yang efektif (Hanafri et al., 2018).

Berdasarkan permasalahan yang sudah dijelaskan maka dalam penelitian ini akan dibahas mengenai suatu aplikasi sistem monitoring kehadiran siswa yang dapat membantu para guru dalam mengontrol kehadiran siswanya dan memberikan laporan yang tepat, cepat dan akurat kepada kepala sekolah.

\section{METODOLOGI PENELITIAN}

\section{Sistem Monitoring Siswa}

Menurut (Setiawan, 2017), monitoring siswa merupakan proses mengawasi siswa dengan tujuan untuk mencegah terjadinya hal-hal yang tidak sesuai dengan rencana pembelajaran yang dapat mempengaruhi tujuan kegiatan belajar-mengajar. Sehingga setiap bagian pendidikan yang terkait langsung dapat menangani masalah tersebut, dan dapat mengambil tindakan terbaik untuk mengatasi penyimpangan yang ada saat ini.

\section{Teknik Pengumulan Data}

Tahapan-tahapan yang dilakukan dalam teknik pengumpulan data adalah sebagai berikut :

a. Pengamatan Langsung / Observasi

Dalam penelitian ini dilakukan pengamatan secara langsung dalam mengamati sistem yang berjalan baik melalui media online maupun offline. Sistem yang diamati dari sisi siswa, mengamati bagaimana saat ini siswa melakukan pembelaran jarak jauh. Dari sisi guru, bagaimana guru melakukan monitoring kehadiran siswanya dan melaporkan kondisi siswanya saat ini.

b. Wawancara

Wawancara dilakukan melalui media online dengan memanfaatkan media telepon ataupun chat menggunakan aplikasi whatsapp.

c. Studi pustaka

Sebagai bahan refrensi yang digunakan dalam penelitian ini, artikel-artikel ilmiah dalam jurnal merupakan refrensi utama yang digunakan. Akses yang mudah merupakan alasan utama mengapa artikel ilmiah digunakan sebagai refrensi dalam penelitian ini.

\section{Model Pengembangan Sistem}

Model pengembangan sistem yang digunakan dalam 
penelitian ini adalah model pengembangan Scrum. Menurut Usman Ependi dalam (Sumarna et al., 2021), "SCRUM adalah bagian dari Agile Development, SCRUM sendiri memiliki kunci kebiasaan yaitu: fokus pada jadwal yang telah ditentukan, mengerjakan sprint secara konsisten, setiap melakukan pengerjaan harus ditandai sebagai product backlog, melakukan sprint berdasarkan product backlog, hasil sprint merupakan tanggung jawab dari scrum master, tim wajib memutuskan produk-produk yang dapat dikembangkan, melakukan pertemuan yang membahas tentang produk dan jadwal pengerjaan, fokus terhadap sprint".

Menurut Joshua Partogi dalam (Firdaus, 2017), Scrum merupakan sebuah kerangka kerha dan bukan metodologi yang tidak boleh dikaitkan dengan metode apapun. Scrum menggambarkan orangorang yang menjalankan proses pengembangan perangkat lunak itu sendiri dan bukan menggambarkan alur tahapan dari proses perangkat lunak.

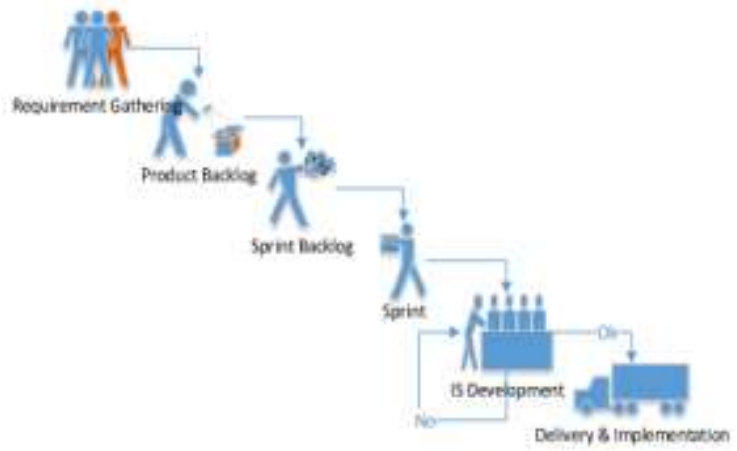

Sumber : (Ependi, 2018)

\section{Gambar 1. Langkah-Langkah Model SCRUM}

Berdasarkan gambar 1, langkah-langkah yang dilakukan dalam penelitian ini adalah sebagai berikut:

\section{a. Requierement Gathering}

Requirement Gathering merupakan tahapan awal dalam model SCRUM. Proses ini dimulai dari pengumpulan data-data yang berkaitan dengan kebutuhan sistem untuk diterapkan dalam proses bisnis dan sistem informasi.

b. Product Backlog

Menurut M. Subekti dalam (Ependi, 2018), tahapan ini dilakukan dengan membuat kelompok dari kebutuhan pengguna yang dihasilkan dari proses pengumpulan kebutuhan yang disebut dengan backlog items. Backlog items terdiri dari daftar fitur dan produk yang diselesaikan yang urut sesuai dengan skala prioitas.

Pada tahap ini dilakukan analisis kebutuhan terhadap sistem informasi monitoring kehadiran siswa sesuai dengan proses bisnis yang berjalan. Analisis kebutuhan dilakukan dengan melibatkan user yang berkaitan dengan proses bisnis, seperti siswa, guru, dan kepala sekolah. Dengan menganalisis masalahmasalah yang terjadi dalam proses bisnis yang berjalan, nantinya akan dihasilkan sebuah solusi yang dapat memecahkan masalah dengan memanfaatkan sistem informasi.

c. Sprint Backlog

Menurut H. Dafitri dalam (Ependi, 2018), Sprint Backlog adalah tahapan untuk memenuhi kebutuhan sesuai backlog items yang sebelumnya sudah dianalisis berdasarakan product backlog atau fase analisis kebutuhan.

Setelah dilakukan analisis kebutuhan pada tahap ini akan dibuatkan sebuah rancangan atau desain sistem berdasarkan kebutuhan dari proses bisnis. Adapun hasil yang di dapat pada tahap ini yaitu rancangan sistem berupa data siswa, data guru, data mata pelajaran, data kehadiran siswa, dan hasilnya dalam bentuk laporan monitoring kehadiran siswa.

d. Sprint

Menurut (Hutrianto \& Putra, 2020), Sprint adalahh tahapan untuk memaparkan hasil produk dalam bentuk prototype kepada pihak klien.

Pada tahapan ini diberikan penjelasan atau pemaparan kepada pihak sekolah yang terlibat dalam proses bisnis mengenai gambaran bagaimana system monitoring kehadiran siswa berbasis web ini akan dibuat, yang akan dijelaskan dalam bentuk prototype produk. Pada tahap ini semua pihak sekolah yang terlibat harus hadir dan mengikuti kegiatan ini.

e. Information System Develpoment

Pada tahap pengembangan sistem, proses yang dilakukan berdasarkan hasil dari tahapan Sprint yang sudah disepakati oleh semua pihak yang terlibat dalam pengembangan sistem. Tahap ini dilakukan sampai pembuatan program selesai dan akan di demokan kembali di hadapan klien dengan semua pihak yang terlibat dalam proses bisnis. Proses ini akan terus dilakukan sampai sistem informasi monitoring kehadiran siswa yang dibuat telah dianggap memenuhi kebutuhan user.

f. Delivery and Implementation

Tahap terakhir dalam model SCRUM yaitu proses delivery and implementation. Tahap ini merupakan penyerahan produk yang dihasilkan yaitu sistem monitoring kehadiran siswa berbasis web kepada pihak sekolah selaku pengguna program. Tahap ini dilakukan setelah tahap pengembangan sistem dianggap selesai. Setelah proses delivery selesai maka akan langsung masuk ke tahap implementasi atau penerapan sistem yang sudah dikembangkan. Pada pose implementasi yang dilakukan yaitu proses instalasi program, dan pelatihan kepada pengguna program.

\section{HASIL DAN PEMBAHASAN}

1. Alur Sistem Monitoring Kehadiran Siswa

Alur sistem monitoring kehadiran siswa berbasis web 
melibatkan dua user yang akan berinteraksi dengan program secara langsung yaitu guru dan kepala sekolah. Alur kerja sistem ini dimulai dari setiap guru mata pelajaran akan memberikan tugas kepada siswa melalui aplikasi media pembelajaran online. Setiap siswa yang sudah selesai mengerjakan dan mengirimkan tugasnya kepada guru sesuai waktu yang ditentukan akan dimasukkan kehadirannya oleh guru tersebut ke dalam aplikasi monitoring kehadiran siswa berbasis web. Setelah guru mata pelajaran menginput data kehadiran siswanya ke dalam system, kemudian wali kelas akan membuat rekap kehadiran siswa selama satu seminggu dan melaporkannya kepada wakil kepala sekolah dan kepala sekolah yang nantinya laporan tersebut dapat digunakan sebagai bahan evauasi kegiatan Pembelajaran Jarak Jauh. Alur sistem ini dapat dilihat pada gambar di bawah ini.

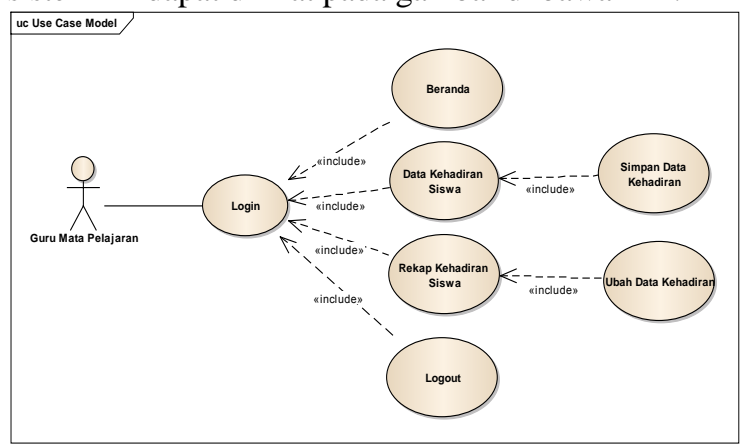

Gambar 2. Use Case Diagram Guru

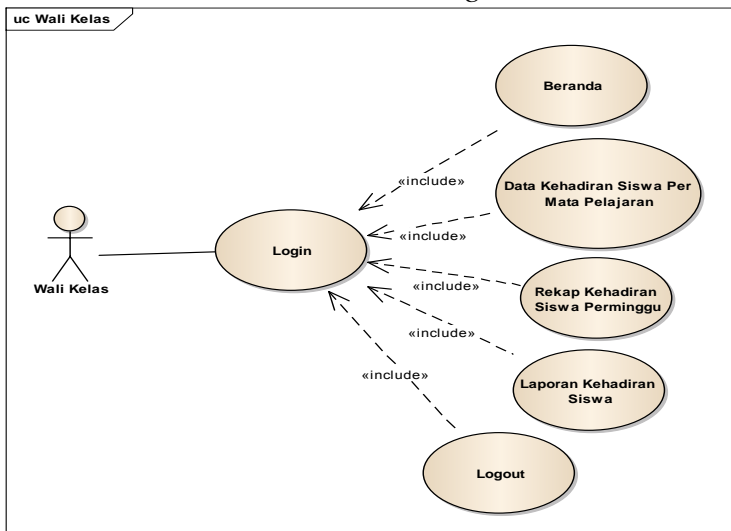

Gambar 3. Use Case Diagram Wali Kelas

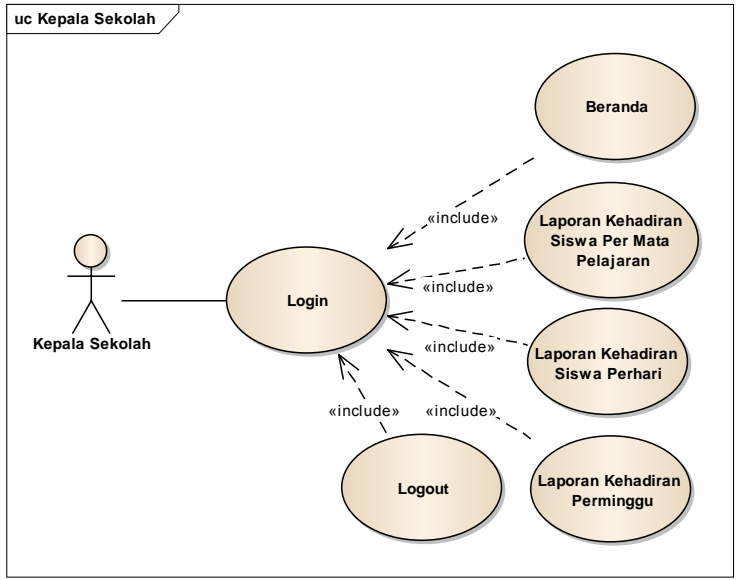

Gambar 4. Use Case Diagram Kepala Sekolah
2. User Interface Aplikasi Monitoring Kehadiran Siswa

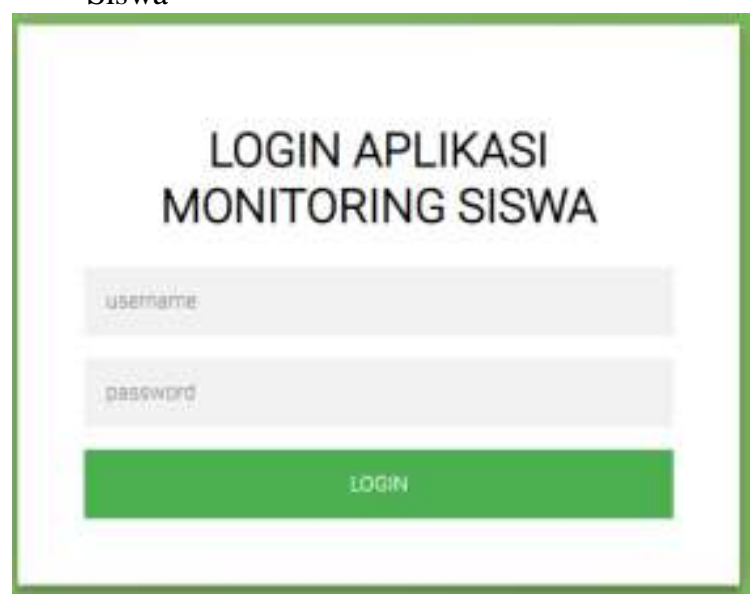

Gambar 5. Tampilan Login

Pada gambar 5, merupakan tampilan halaman login user. Dimana user yang dimaksud yaitu guru, wali kelas, dan kepala sekolah.
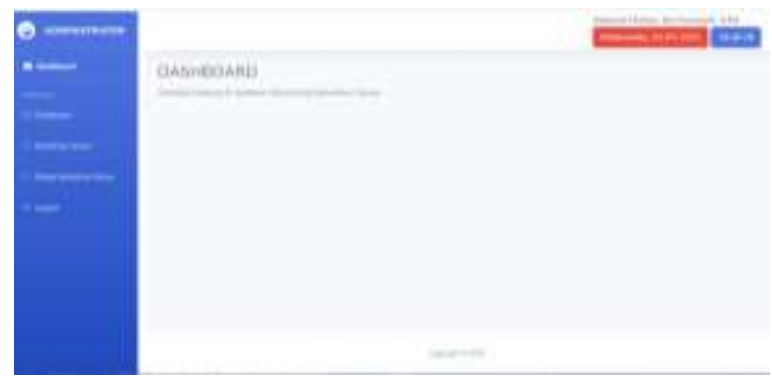

Gambar 6. Tampilan Menu Utama

Pada gambar 6, merupakan tampilan menu utama untuk guru yang terdiri dari menu kehadiran siswa, dan rekap kehadiran. Pada halaman ini guru akan melakukan presensi kehadiran siswa setiap jadwal mata pelajarannya.

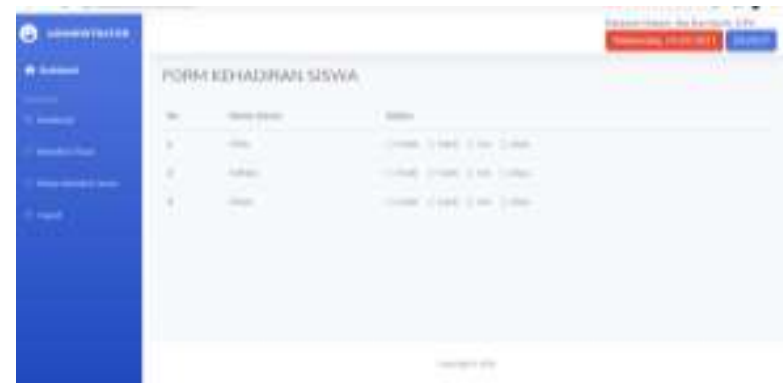

Gambar 7. Tampilan Kehadiran Siswa

Gambar 7 menunjukkan tampilan halaman kehadiran siswa yang dilakukan oleh guru.

\section{KESIMPULAN}

Berdasarkan hasil penelitian yang sudah dilakukan dapat disimpulkan bahwa dengan adanya aplikasi 
monitoring kehadiran siswa dapat memudahkan guru maupun wali kelas dalam melakukan pengolahan data kehadiran siswa secara cepat, tepat dan akurat. Dengan adanya laporan kehadiran siswa yang akurat dapat membantu pihak sekolah yang terkait dalam proses evaluasi sistem Pembelajaran Jarak Jauh dan juga sebagai bahan pertimpabngan kepala sekolah dalam pengambilan keputusan. Diharapkan pada penelitian di masa yang akan datang dapat dilakukan pengujian terhadap efektifitas aplikasi tersebut terhadap kegiatan Pembelajaran Jarak Jauh dan pengaruhnya terhadap prestasi siswa selama mengikuti pembelajaran di masa pandemi covid-19.

\section{REFERENSI}

Ependi, U. (2018). Implementasi Model Scrum pada Sistem Informasi Seleksi Masuk Mahasiswa Politeknik Pariwisata Palembang. Jurnal Informatika: Jurnal Pengembangan IT, 3(1), 49-55.

http://ejournal.poltektegal.ac.id/index.php/info rmatika/article/view/640

Firdaus, M. A. (2017). Implementasi Kerangka Kerja Scrum Pada Manajemen Pengembangan Sistem Informasi. Seminar Nasional Teknologi Informasi Dan Multimedia 2017, 1(2), 283288.

Hanafri, M. I., Triono, \& Luthfiudin, I. (2018). Rancang Bangun Sistem Monitoring Kehadiran Dosen Berbasis Web Pada STMIK Bina Sarana Global. Jurnal Sisfotek Global, Vol.8(No.1), 81-86. http://journal.stmikglobal.ac.id/index.php/sisfo tek/article/view/175

Hutrianto, H., \& Putra, A. (2020). IMPLEMENTASI SCRUM MODEL DALAM PENGEMBAGNAN APLIKASI pelAPORAN SAMPAH SEBAGAI WUJUD SMART CLEANING. JIPI (Jurnal Ilmiah Penelitian Dan Pembelajaran Informatika), 5(1), 9. https://doi.org/10.29100/jipi.v5i1.1552

Kurniawan, F. I., \& Akbar, R. M. (2020). Pengembangan dan analisis kualitas sistem monitoring kegiatan belajar mengajar siswa tingkat sekolah menengah atas negeri di Indonesia. Teknologi, 10(1), 10 https://doi.org/10.26594/teknologi.v10i1.1941

Putri, M. E., Ayu, D., \& Wulandari, N. (2016). Sistem Informasi Monitoring Siswa Berbasis Web Dan SMS Gateway Pada SMK Negeri 37 Jakarta. Jurnal Teknik Komputer, II(2), 49-55. https://ejournal.bsi.ac.id/ejurnal/index.php/jtk/ article/view/1620

Riyandi, A., Aulianita, R., Wiyatno, A., Triantori, V., \& Musyaffa, N. (2020). Pemanfaatan Teknologi untuk Pembelajaran Jarak Jauh di Masa Pandemi Covid-19. Jurnal AbdiMas Nusa Mandiri, 2(2), 37-42. https://doi.org/10.33480/abdimas.v2i2.1682

Rosmiati, M. (2020). Sistem Informasi Penerimaan Peserta Didik Baru Berbasis Web. Indonesian Jurnal on Software Engineering, 6(3), 182.

Setiawan, F. (2017). Aplikasi Monitoring Kehadiran Siswa Smkn 1 Bandung Berbasis Android. JATI (Jurnal Mahasiswa Teknik Informatika), 1(1), 747-754.

Sumarna, S., Suhendry, M. R., Riana, E., Riyanto, V., \& Nurdin, H. (2021). Rancang Bangun Learning Management System Menggunakan Framework CodeIgniter Pada PT. Rekayasa Industri. Jurnal Teknik Komputer, 7. 